\title{
Inter-firm cooperation and seller trade practices: empirical investigation of small firms
}

\author{
Sebhatleab Tewolde $(\mathrm{PhD})$, Mussie T. Tessema $(\mathrm{PhD})$ \\ Associate Professor of Finance and Accounting, College of Business and Economics, University of \\ Asmara, Eritrea. \\ Associate professor, Business Administration Dept., Winona State University, USA MN. Som323F.
}

\begin{abstract}
The purpose of this study is to assess the trade practices used by firms in developing countries using Eritrea as a case. The study specifically focuses on the effects of cooperation between suppliers and their customers on the sellers' trade approaches. It examines what types of trade approaches firms use (cash, credit, and/or both), how they apply their approaches and why they choose those approaches. Then it studies if these approaches are influenced by the existence of inter firm cooperation or networking (as measured by association, information, trust, supplier concentration and transaction cost) between supplier firms and their customers. This study indicates that the firms use more personal visits to communicate among themselves and the overwhelming majority of them do not belong to any business association. Firms which have network or association with established relationship and trust sell more on both credit compared to those which do not have. The firms, who believe that the transaction cost is expensive, relatively sell less on both credit and cash compared to those which said "it is not". Implications of these findings and future research directions are discussed.
\end{abstract}

Keywords: Trade, cash, credit, buyer-supplier relationship, developing countries, Eritrea.

\section{Introduction}

Firms may be financed by their suppliers using trade credit rather than by financial institutions. Firms need finance to operate and make short-term and long-term investments. Finances can be generated internally by retaining profits or funds obtained externally through the injection of capital or getting credit (or loan) from financial or non-financial organizations. The first option is more difficult and expensive for small and new firms (Coleman, 2003; Wilner, 2000), as it is the case with most of the business firms in Eritrea, because it requires successful business operation. The second option is neither easy for these firms because it requires trust of the lender. Moreover, the generation of financing power by building up trust may relatively be easier in the shortterm than generating it internally. Most firms in the developing world and specifically in Africa and by default in Eritrea are small (in terms of capital base and sales/profit) and therefore presumably getting problems of external financing both in the short and in the long-term. This problem could be solved by trading on properly applied credit terms (Coleman, 2003).

Trade credit is credit extended by a seller who does not require immediate payment for delivery of a product. It is an important source of funds for business customers. In 1987, in the United States, such credit accounted for about 15 percent of the liabilities of nonfarm nonfinancial businesses and nonmortgage loans from banks (Gregory and John, 1993). Gregory \& John (1993) found also that, trade credit accounted to about 20 percent of small firms' liabilities in the USA. Credit can be classified depending on the nature of the debtor/creditor as well as purpose of credit and time length. The debtor/creditor classification of credit includes business credit, individual credit, and government credit. Business credit among others includes trade credit, consumer credit, as well as short- medium- or long-term credit (McMilan \& Woodruff, 1999). Our concentration here is on the short-term trade credit, which arises when firms sell goods and services with the postponement of cash receipt to the short term future. It is the exchange of goods or services on trust between a party which has the goods or services and another which needs them. Trade credit has potential benefit for both the seller and the buyer (Macaulay, 1963; Peel et al. 1999; Haley 1997; McMilan \& Woodruff, 1999; Williamson, 1985; Bias, 1997). The buyer gets time to investigate quality of goods before paying (quality control) and to increase its purchasing power without the need to pay cash immediately (cash management) (Pike et al., 2005; NG, Smith, \& Smith, 1999; Coleman, 2003; Petersen \& Rajan, 1994). The seller can use trade credit to stimulate demand and therefore increase sales, discriminate customers on the basis of price, establish reputation, reduce cost of inventory etc., (Miksomovic \& Zechner, 1988; Kartz, 1984; Holmes, 1989; Pike et al., 2005).

The dual business objectives of firms are the profitability objective - creation of value to investors by increasing revenues/cash inflows and deceasing costs/cash outflows on one hand and the liquidity objective controlling the risk of liquidity on the other. One of the major tools that help in the achievement of these objectives is a policy of trade credit. Trade credit helps to create value to investors by increasing revenues but 
potentially exposes business firms to risk of liquidity because it may decrease cash inflows by postponing cash collection to the future (NG et al., 1999).

The use of trade credit depends upon the prevailing characteristics of the firm, the product and the environment. Researchers (e.g., Pike et al., 2005; Marotta, 2005; McMillan \& Woodruf, 1999; Deloof \& Jegers, 1996) have found out that the characteristics of firms have different applicability in both developed and developing countries and considerable research has been conducted to assess the trade credit determinants. Yet, previous research has given little attention to trade credit determinants in the developing countries, like Eritrea. However, the prevalence, use and influence on trade practice of these characteristics on Eritrean business firms, is yet to be researched. So far as the researchers' knowledge is concerned, there has been no research made with an objective to find the motive, the extent nor the types of trade credit used by the business firms in Eritrea. This study therefore deals with the effect of inter-firm cooperation on seller trade practice and tries to find answers for:

1. What are the sellers' trade approaches used by the business firms in Eritrea?

2. Does inter-firm cooperation influence the sellers' trade approaches?

\section{Literature Review}

The theoretical arguments employed in this paper are based on the insights from working capital management (Van Horn, 1998; Scherr, 1989), value chain model (Porter, 1985), value network model (Rappaport, 1986), firm-supplier-customer linkages management (Shank \& Govidaradjan, 1993), and transaction cost economics theory (Williamson, 1985). As per our literature review, whether a firm is to trade on credit, on cash or on both credit and cash will depend upon certain characteristics including: Firm characteristics, product characteristics and environmental characteristics. Moreover, the main focus of this study is on firm characteristics.

Firm characteristics refer to firm's own characteristics (liquidity, profitability, size, age, \& trade credit policy), inter firm linkages with suppliers and customers (information, reputation/trust, networking, customer/supplier concentration, transaction cost), and firm bank relationship. This study focuses on the effect of inter firm linkages (or cooperation) with suppliers on trade credit (cash, credit and/or both). It specifically evaluates availability of information, existence of reputation/trust, networking, customer/supplier concentration and transaction cost and studies their effect on buyer's trade practice.

Studies show that availability of information measured using experience of business relationship and membership in network can be Symmetric or Asymmetric. When it is symmetric, sellers and buyers use more trade credit, because sellers have enough information about the risk and may be willing to sell on credit to the less risky buyers. When it is asymmetric, sellers and buyers use less trade credit. In order to reduce information asymmetry, sellers may offer two part trade credit terms with effective annual rate of interest well above the buyers marginal cost of capital and wait and see the reaction, signalling the payment risk (NG et al., 1999; Pike, et. al., 2005).

Reputation and trust can be evaluated using number of years of business relationship with most loyal customers and suppliers. When reputation and trust is well established, sellers and buyers - use more trade credit. Sellers establish their reputation by including themselves into a network so that the information distribution both speed and quality is enhanced. Established relationship creates trust and minimizes the moral hazard with buyers and sellers and therefore trade on credit terms. Moreover, two part trade credit is offered to reward relationship by paying "unearned" discount to long term customers (Pike et al., 2005; McMillan, \& Woodruf, 1999: NG et al., 1999; Smith, 1987). When reputation and trust is not established, sellers and buyers use less trade credit - With no prior knowledge of each other, trade partners prefer cash transactions until the repetition creates reputation and trust.

Networking measured by the existence of communication with network group can be used to study trade practices. When networking exists, sellers and buyers - use more trade credit. Networking helps the distribution of information and reduces information asymmetry and increases trust. If buyers and sellers belong to a well-organized network of business group and have accredited name of being creditworthy, they can buy and sell on credit (McMillan, \& Woodruf, 1999; NG et al., 1999). When networking does not exist, sellers and buyers - use less trade credit. If buyers and sellers do not belong to a well-organized network of business group and have no accredited name of being creditworthy, they can only trade (buy and sell) on cash basis. Cole, (1998), find that a potential lender is more likely to extend credit to a firm with which it has a pre-existing relationship as a source of financial services, but that the length of this relationship is unimportant.

Customer/Supplier concentration measured by the number of regular customers/suppliers that a buyer or seller has can be used to study trade practices. When Customer/ Supplier concentration exists, sellers and buyers - use more trade credit. Fewer customers means less information asymmetry, more trust and therefore both sellers and buyers will be willing to trade on credit (Mian \& Smith, 1992). Creditors are more likely to finance credit constrained firms when credit markets are concentrated because it is easier for creditors to 
internalize the customers' benefits share in the future surplus and creditors can also use price discrimination easily when customer base is concentrated (Mian \& Smith, 1992). When customer/ Supplier concentration does not exist, sellers and buyers - use less trade credit. Sellers and buyers use less trade credit because inter-firm relations and trust are loose and multiple trade creditors decrease the availability of trade credit and increase the cost of trade (Petersen, \& Rajan, 1994).

The extent of transaction cost can measured by managers' opinion on the consequence (possibility of getting another loyal customer soon or cost of losing the old and finding new) of changing loyal customers. When there is high transaction cost - Sellers and buyers - use less trade credit. In order to protect themselves against potential opportunist partner, both buyers and sellers put internal and external managerial safeguards. This creates pre and post transaction costs, which increase with incomplete transaction of trade credit, therefore both sellers and buyers, use less of it. However, when there is low transaction cost - Sellers and buyers - use more trade credit. Where there is no potential opportunist partner, both buyers and sellers do not need to put internal and external managerial safeguards and transaction costs of trade credit decreases, therefore both sellers and buyers use more of it.

Firms may be financed by their suppliers using trade credit rather than by financial institutions. Trade credit is the single most important source of short term external finance for firms in the United States (Rajan \& Zingales, 1993, as quoted by Petersen \& Rajan, 1997). Credit is a term that originated from the Latin word "credo" (Sanskrit Latin 'CRAD') meaning ones confidence in another. Credit is the exchange of goods or services on trust (that debtor pays) between a party which has the goods or services and another which needs them. The exchange transaction is completed when the debtor pays back.

Credit can be classified depending on the nature of the debtor and creditor, purpose of credit and time length. The debtor/creditor classification of credit includes business credit, individual credit, and government credit (Rajan \& Zingales, 1993). Types of business credit include trade credit, consumer credit, production credit, speculative credit, short- medium- or long-term credit, monetized and non-monetized credit, financial credit, commercial credit, investment credit, foreign trade credit, industrial credit and agricultural credit. Our concentration here is on the trade credit, which arises when firms sell goods and services with the postponement of cash receipt to the future, which is widely used particularly in the developed world. For example in the UK corporate sector it is estimated that more than $80 \%$ of daily business to business transaction is on credit terms (Peel et al., 1999).

When approached by a potential buyer, there are three options for a seller. The seller can require the buyer to pay cash before delivery (CBD), to pay cash on delivery (COD) or pay cash after delivery (CAD). If the buyer is required to pay cash after delivery, it means that the seller is offering a trade credit, increasing the buyers purchasing power and decreasing the sellers purchasing power, albeit temporarily.

Trade credit can have two options - net trade credit (e.g. n/30, n/EOM) and two part trade credit (2/10, $\mathrm{n} / 30$ ) (NG et al., 1999). The net trade credit refers to the option where the buyer is required to pay the net (of sales returns and sales allowances) at least on a certain date, 30 days or End of Month in our example. The two part trade credit gives two options for the buyer, to pay by at least on certain day of the credit period and get discount, (the tenth day after purchase and get a certain discount, that is $2 \%$ on the net purchase in our example), if this opportunity is not used then the buyer pays the net trade credit by the last date indicated $\left(30^{\text {th }}\right.$ day in our example). As it can clearly be observed, the two part trade credit gives an incentive to the buyer to get $2 \%$ discount which effectively means a discount of $43.9 \%$ per year (NG et al., 1999).

Why do business firms extend trade credit when specialized financial institutions such as banks could provide the finance? There are many theoretical reasons for trade credit which are beneficial to trade sellers, buyers and to both (Tewolde, 2002; Tewolde and Eije, 2007). Specific motives for trade credit to the seller may include: to stimulate Demand and to meet a temporary deficit in demand with a temporary relaxation in payment terms (Emery, 1987); to discriminate customers on the basis of price (Brenan, Miksomovic, \& Zechner, 1988; Holmes, 1989; Pike et al., 2005; Petersen \& Rajan, 1994, NG et al., 1999); to decease precautionary money holdings (Ferris, 1981; Emery, 1987); to use sellers comparative advantage to get short-term bank loan to finance credit-constrained firms when credit markets are concentrated (Petersen \& Rajan, 1997; Coleman, 2003; Coleman, 2003; Danielson, 2004); to take advantage of size by larger firms (Brenan, Miksomovic, \& Zechner, 1998; NG et al., 1999; Coleman, 2003; Pike et al. 2005; Wilner, 2000); to exploit greater market power when there is customer concentration (Mian \& Smith, 1992; Petersen \& Rajan, 1994); and to recover products if they can serve as collateral (NG et al., 1999).

The buyer can also use trade credit in order to control quality of goods purchased and manage cash - as quality control and cash management tools (Scherr, 1996); to bypass credit rationing when customer gets it difficult to find an alternative supplier of finance due to supplier network (Petersen \& Rajan, 1994; McMillan \& Woodrruf, 1999); to solve problems of access to public debt and equity markets for small and new firms (Coleman, 2003). 
Both buyers and sellers can use trade credit for a number of reasons. Some of the important reasons are: to reduce uncertainty when there are informational asymmetries between buyers and sellers (Pike, et al., 2005; NG et al., 1999); to reduce transactions costs due to opportunistic behaviour (Williamson, 1985); to use as a substitute for a legal system that cannot enforce a trade credit contract (Marotta, 2005; Macaulay, 1963; McMilan \& Woodruff, 1999).

Firm characteristics refer to firm's own characteristics (liquidity, profitability, size, age, \& trade credit policy), inter firm linkages with suppliers and customers (information, reputation or trust, and networking, customer/supplier concentration), transaction cost, and firm bank relationship. This study, however, will focus on the effect of liquidity, profitability, size, and age of a firm on the use of cash, credit and/or both.

Studies show that liquid sellers tend to lend customers by offering trade credit, thereby acting as financial intermediaries outside the financial markets and maximize the rate of return on liquid assets in imperfect (absent) financial markets (e.g., Petersen \& Rajan, 1997). The higher the profit margin, the more likely the seller is to offer trade credit, because it can afford to accept lower profit or to incur if it happens a greater loss. Small selling firms solve the problem of seller reputation by selling on credit and having longer days that accounts receivable are outstanding, so that they use it to guarantee the quality of their product and to strengthen seller -buyer relationship. Small buying firms use trade credit because they are credit rationed so cannot have the required internally generated financial power and they cannot guarantee banks with their asset base as collateral (Coleman, 2003; Wilner, 2000). Large firms can buy and sell on credit because they have the asset base for collateral, can borrow money and can pay within the discount period if there is the option, they have the experience and the reputation in the business and therefore the trust by sellers (Brenan et al., 1998; Coleman, 2003). Young and expanding firms are less liquid and cannot afford to sell on credit, they cannot finance receivables by borrowing from banks because they are credit rationed. They cannot buy on credit because they have no asset base for collateral nor the experience and reputation to prove their trustworthiness Coleman, 2003; Wilner, 2000). Firms which have established trade credit policy to maximize sales tend to use more trade credit (Coleman, 2003).

\section{The research methodology}

For this study we have followed Bouma and Atkinson (1995) proposal. They propose an outline of three phases in the research process. The first phase requires a researcher to clarify the issues to be researched and select a research method. In this phase the researcher has to select, narrow and formulate the problem to be studied, select the research design, design and devise measures for variable, set-up tables for analysis and select a sample or the units of analysis. The second phase concerns the collection of data about the research question, summarizing and organizing the data. The third and final stage relates to the analysis and interpretation of data including relating data to the research question, drawing conclusions, assessing the limitations of the study and making suggestions for further research.

\section{Measures}

Drawing on the literature review and guided by the research framework, first the variables/concepts considered relevant to the study have been identified, defined conceptually and operationalized. The second step was the preparation of the questionnaire and execution of a pilot study on 10 respondents (firms' managers). A pilot study was done in order to test whether [a] the questionnaire would enable us to gather the desired data, and $[\mathrm{b}]$ the respondents understand the concepts and measurements. After conducting the pre-test or pilot study and making all necessary adjustments, 200 questionnaires were distributed to the respondents.

A cross-sectional survey research method is chosen as a preferred method for our research using exploratory and descriptive study approaches. Our survey generalizes the trade practice used by all business firms in Eritrea from a sample of 200 firms at Zoba Maekel. We have preferred the survey approach due to its advantage over economy, speed of data collection and its advantage in identifying attributes of a population from a small group of individuals (Creswell, 1994). We distributed questionnaires to 200 firms (from the manufacturing, service and merchandising business sectors) of which 100 were sellers and 100 were buyers. In addition to the questionnaires, data has also been collected from the firms' financial statements of five years (2004 to 2008). All respondents returned the questionnaires (100\% response rate). The 200 firms (sample) were randomly selected from the 2205 firms of the Central Zone, provided by the Ministry of Industry and Trade (MoTI, 2010). The Central Zone is the most industrial region of the country.

Firms' managers were asked to give us their opinions on their trade credit policy and practice. For example, managers are asked (a) what trade approaches they use (cash or trade credit or both) and (b) how they apply their approaches or (c) why they do not apply otherwise. Most questions provide a number of alternative answers and end-up with "others" so that the managers input their own reasoning. In administering questionnaire, data collectors were properly selected in that they all had a minimum of diploma in accounting with very good grade in working capital management. Second, they were given orientation on the objectives and 
data collection approaches. Third, they were given official letters introducing the researcher and the data collector. Fourth, they contacted each respondent personally or by telephone. On the appointment date the data collector hands over official letters that identify the researcher and data collector. The data collector then explained the objective of the study and how the respondent can fill in and then submit the questionnaires. This may take around 30 minutes. At least one reminder call is made by the data collector a day before the date of the appointment. When collecting the questionnaire about 15 minutes is taken to explain questions that the manager may have and appointment made for the conduct of interview. Upon collection, the questionnaire is imputed to the data summary sheet and notes of inconsistencies or unfilled questionnaires taken.

This study aims at finding out if information exchange obtained through experience of business relationship including - membership in network or an association, concentration of regular customers and transaction cost influence the use of trade credit in the business firms of Eritrea. As a proxy to measure the above factors we used the managers' opinion on the experience of business relationship, membership in network, customer concentration, established trust and transaction cost.

As a proxy to obtain and measure information we used the managers' opinion - (a) on the firms' trade practice, (if they trade on cash, credit or both), (b) then obtained information on the firms' experience of business relationship, membership in network, supplier concentration, established trust and transaction cost, and finally, we assessed if (a) is influenced by (b). We expected that sellers having longer business experience with customers, or having membership in network or association, concentrated number of customers, established trust and lower transaction cost to trade more on credit than on cash.

For this purpose, we divided the firms into three categories - firms with business relationship of less than 10 years, between 10 and 30 years and those with more than 30 years. We measured supplier concentration in terms of number of suppliers. With this objective in mind, the firms are divided into three categories - those with few suppliers (less than 10 suppliers), those with average number of suppliers (between 10 and 30 suppliers) and those with large number of suppliers (more than 30 suppliers). On the basis of years of business experience we divided the firms into three categories - firms with business relationship less 10 years, between 10 and 30 years and those with more than 30 years of business experience.

On networking and inter business cooperation, we expected that sellers with symmetric information or those who have enough information about the buyers also know the risk and may be willing to sell on credit to the less risky buyers. Sellers with longer business experience with the buyers, membership in network or association, concentrated customer, established trust and lesser transaction cost may be willing to sell on credit to the less risky. Conceptually, sellers with asymmetric information want to reduce information asymmetry, and may offer two part trade credit terms with effective annual rate of interest well above the buyers marginal cost of capital and wait and see the reaction, signalling the payment risk (NG et al., 1999; Pike et al., 2005). We asked managers four different questions to know the inter-firm relationships including: if they (a) communicate with managers (employees) of other organizations which deal in similar businesses to that of theirs and if the answer is yes, how they communicate, (b) how many regular customers they have and (c) if they believe that the transaction cost of changing loyal customer (due to problem of getting another customer soon or cost of losing the existing and finding a new) is expensive for them.

Data that has been collected using questionnaires, interviews and archival records are analysed in the next section. The primary data collected using questionnaires and interviews are used to study the approaches of trade credit used by the Eritrean firms. The secondary data collected from financial statements are used to study the implication of the managerial approaches particularly on liquidity and profitability. The empirical data collection is divided into (a) sellers' responses and (b) the effect of the responses on their trade approaches ("cash only", "credit only" or a combination of the two - "both on credit and cash"). Moreover, our findings clearly show that the "credit only" option is used by very insignificant number of respondent firms. So, we reframed the analysis to include a comparison between the "cash only" on one hand and the "both credit and cash" on the other. If majority of respondents are in favour of one choice ("cash only" or "both credit and cash"), then we see which uses more of the chosen option, that is, "cash only" or "both credit and cash".

\section{Findings}

Data that has been collected using questionnaires, interviews and archival records are analysed. The primary data collected using questionnaires and interviews are used to study the approaches of trade credit used by the Eritrean firms. The secondary data collected from financial statements are used to study the implication of the managerial approaches particularly on liquidity and profitability. The findings are presented as follows:

Table 1: Sales policy

\begin{tabular}{|l|l|l|l|l|l|l|l|l|}
\hline \multirow{2}{*}{ On what terms do you sell? } & \multicolumn{4}{|l|}{ Terms of Purchase } & \multicolumn{4}{l|}{ If both on credit and cash - proportion } \\
\cline { 2 - 10 } & Cash & Credit & Both & Total & More Cash & More Credit & Equal & Total \\
\hline Respondents (No.) & 38 & 0 & 62 & 100 & 60 & 7 & 5 & 76 \\
\hline
\end{tabular}




\begin{tabular}{|l|l|l|l|l|l|l|l|l|}
\hline Respondents (\%) & $38 \%$ & 0 & $62 \%$ & $100 \%$ & $83 \%$ & $10 \%$ & $7 \%$ & $100 \%$ \\
\hline
\end{tabular}

As table 1 reveals, relatively more firms (62\%) sell both on cash and credit compared to the $38 \%$ that sell only on cash. Out of the 76 firms that sell both in cash and credit $83 \%$ sell more on cash and $10 \%$ sell more on credit and only $7 \%$ said they sell equally on cash and credit.

Table 2: characteristics of customers buying on cash only

\begin{tabular}{|l|l|l|l|l|l|l|}
\hline \multirow{2}{*}{ Who buys on cash? } & \multicolumn{3}{|c|}{ Time relationship started } & \multicolumn{3}{c|}{ Size of customers } \\
\cline { 2 - 8 } & New & Old & Total & Small & Large & Total \\
\hline Respondents (No.) & 73 & 51 & 124 & 42 & 22 & 64 \\
\hline Respondents (\%) & $59 \%$ & $41 \%$ & $(100 \%)$ & $66 \%$ & $34 \%$ & $(100 \%)$ \\
\hline
\end{tabular}

As table 2 indicates, according to the opinion of the sellers, taking the time of inter firm relationship (new/old) and size of trading partner, (small/large) into account, out of those who buy on cash- 59\% are new customers, $41 \%$ are old (long relational experience). However, when size is taken as a point of reference, $34 \%$ are large and $66 \%$ are small.

Table 3: Why Trading (Selling) only on cash

\begin{tabular}{|l|l|l|}
\hline \multirow{2}{*}{\multicolumn{2}{c|}{ Why do seller sell and buyers buy on cash? }} & \multicolumn{2}{c|}{ Sellers } \\
\cline { 2 - 3 } & Respondents (No.) & Respondents (\%) \\
\hline Selling/buying on credit is not necessary & 17 & $19 \%$ \\
\hline Offering credit is not customary & 21 & $24 \%$ \\
\hline It is difficult to identify trustworthy customer & 28 & $32 \%$ \\
\hline Other & 23 & $26 \%$ \\
\hline Total & 89 & $100 \%$ \\
\hline
\end{tabular}

As to why the firms trade on cash (see table 3), $32 \%$ of sellers said because it is difficult to identify trustworthy customers, $24 \%$ said because offering credit is not customary, $19 \%$ said because selling on credit is not necessary, and $26 \%$ said because of other reasons.

Table 4: Characteristics of customers buying in credit

\begin{tabular}{|l|l|l|l|l|l|l|}
\hline \multirow{2}{*}{\multicolumn{1}{c|}{ Who buys on cash? }} & \multicolumn{3}{|c|}{ Relationship } & \multicolumn{3}{c|}{ Size of customers } \\
\cline { 2 - 8 } & New & Old & Total & Small & Large & Total \\
\hline Respondents (No.) & 2 & 57 & 59 & 5 & 26 & 31 \\
\hline Respondents (\%) & $3 \%$ & $97 \%$ & $100 \%$ & $16 \%$ & $84 \%$ & $100 \%$ \\
\hline
\end{tabular}

On the issue of credit (see table 4), we assessed who (new/old, small/large) and why (necessity, culture, trust) the firms trade on credit. According to the opinion of the sellers, $97 \%$ of the customers who buy on credit are old (with long relational experience), and 3\% are new, while $84 \%$ are large and $16 \%$ are small.

Table 5: Why Trading (Selling) only on credit

\begin{tabular}{|l|l|l|}
\hline \multirow{2}{*}{ If you sell on credit, why do you sell on credit? } & \multicolumn{2}{c|}{ Sellers } \\
\cline { 2 - 4 } & Respondents (No.) & Respondents (\%) \\
\hline To increase sales & 10 & $13 \%$ \\
\hline To create customer confidence & 25 & $33 \%$ \\
\hline Both & 28 & $37 \%$ \\
\hline Other & 13 & $17 \%$ \\
\hline Total & 76 & $100 \%$ \\
\hline
\end{tabular}

As table 5 reveals, on why on credit, $33 \%$ of sellers sell on credit in order to create customer confidence, $13 \%$ to increase sales, $37 \%$ both to increase sales and create customer confidence and for other reasons $(17 \%)$.

Table 6: Actions taken overdue customers

\begin{tabular}{|l|l|l|}
\hline \multirow{2}{*}{ Action taken if payment is not done within agreed time. } & Sellers & Respondents (\%) \\
\cline { 2 - 3 } & Respondents (No.) & $18 \%$ \\
\hline Give more time & 16 & $25 \%$ \\
\hline Communicate orally, in written, in person. & 22 & $21 \%$ \\
\hline Stop selling on credit until the debt is paid & 19 & $34 \%$ \\
\hline Solve the case amicably & 30 & $0 \%$ \\
\hline Take the case to the court & 0 & $2 \%$ \\
\hline Other & 02 & $100 \%$ \\
\hline Total & 89 & \\
\hline
\end{tabular}


As table 6 shows, on issue of actions taken against overdue customers, $34 \%$ of seller respondents said that they solve the case amicably, $25 \%$ communicate orally, in written; in person before taking any action, $21 \%$ stop selling on credit until the debt is paid, $18 \%$ give more time. All sellers said that they do not take the case to the court. Only $2 \%$ said that they use other mechanisms.

Table 7: Business experience - Information Symmetry, Reputation

\begin{tabular}{|l|l|l|l|l|}
\hline $\begin{array}{l}\text { How long (in years) have you been trading } \\
\text { with your oldest customer- } \\
\text { Inter business cooperation in years? }\end{array}$ & Number of respondents & \multicolumn{3}{|l|}{ Trading on cash/credit } \\
\cline { 3 - 6 } & & Cash only & Credit only & Both \\
\hline Less than 10 years & $51(54 \%)$ & $21(41 \%)$ & 0 & \\
\hline Between 10 \& 30 years & $41(43 \%)$ & $11(27 \%)$ & 0 & $30(59 \%)$ \\
\hline More than 30 years & $3(3 \%)$ & $2(67 \%)$ & 0 & $30(73 \%)$ \\
\hline Total & $95(100 \%)$ & $34(35 \%)$ & & $1(33 \%)$ \\
\hline
\end{tabular}

On the issue of inter-business experience (see table 7) as a measure of information symmetry, reputation or trust, 95 managers responded out of which 54\% said that they have less than 10 years inter firm cooperation, $43 \%$ said that they have between 10 and 30 years of experience and only $3 \%$ said have more than 30 years of experience. Comparing inter-business experience with trade credit reveals that out of the 51 firms with less than 10 years of inter-business experience, 59\% said that they sell both on credit and cash while $41 \%$ sell only on cash. Only $2 \%$ sell on only credit. From the 41 firms with inter-firm experience between 10 and 30 years, $73 \%$ sell both on credit and cash while $27 \%$ sell only on cash. From the firms with the longest relationship on inter-business cooperation (more than 30 years), 33\% sell both on credit and cash and $67 \%$ sell only on cash.

Table 8: Net working with other firms - existence of communication

\begin{tabular}{|l|l|l|l|l|}
\hline \multirow{2}{*}{ Communication with other firms } & \multirow{2}{*}{ No of firms } & \multicolumn{3}{|l|}{ Trading on cash/credit } \\
\cline { 3 - 5 } & & Cash only & Credit only & Both \\
\hline Yes & $84(85 \%)$ & $29(35 \%)$ & 0 & $55(65 \%)$ \\
\hline No & $15(15 \%)$ & $9(60 \%)$ & 0 & $6(40 \%)$ \\
\hline Total & $99(100 \%)$ & $38(38 \%)$ & 0 & $61(62 \%)$ \\
\hline
\end{tabular}

As table 8 indicates, empirically, 99 firms responded on whether they have formal communication with their suppliers or not, out of which $85 \%$ out of which said yes they communicate while the $15 \%$ said they do not communicate at all. Comparing networking vs trade credit shows that out of the 84 firms which said they do communicate $65 \%$ sell both on credit and cash while $35 \%$ sell only on cash. On the other hand out of the 15 firms which said "no" for communication, $40 \%$ sell both on credit and cash and $60 \%$ sell on cash.

Table 9: Networking- means and frequency of communication

\begin{tabular}{|l|l|l|l|l|l|l|l|l|l|}
\hline \multicolumn{9}{|c|}{ Means of communication } & \multicolumn{3}{|c|}{ Frequency of communication } \\
\hline Telephone & Letter & $\begin{array}{l}\text { Personal } \\
\text { visits }\end{array}$ & $\begin{array}{l}\text { Business } \\
\text { association }\end{array}$ & Other & $\begin{array}{l}\text { Total } \\
\text { answers }\end{array}$ & $\begin{array}{l}\text { When } \\
\text { approached }\end{array}$ & Regularly & $\begin{array}{l}\text { Other } \\
\text { answers }\end{array}$ \\
\hline $33(26 \%)$ & $15(12 \%)$ & $66(52 \%)$ & $10(8 \%)$ & $2(2 \%)$ & $126(100 \%)$ & $15(19 \%)$ & $52(64 \%)$ & $14(17 \%)$ & $81(100 \%)$ \\
\hline
\end{tabular}

On means of communication (see table 9), from those who communicate, $52 \%$ do personal visits, $26 \%$ said that they use telephone, $12 \%$ send letters, $8 \%$ have business association, and $2 \%$ use other methods to communicate. Regarding frequency of communication 81 firms responded out of which $64 \%$ said regularly, $19 \%$ when approached by a new customer and $17 \%$ use other mechanism.

Table 10: Customer concentration

\begin{tabular}{|l|l|l|l|l|}
\hline & Total respondents & \multicolumn{3}{l|}{ Trading on cash/credit } \\
\cline { 3 - 5 } Customer concentration & & Cash only & Credit only & Both \\
\hline Few less than 10 & $16(16 \%)$ & $8(50 \%)$ & 0 & $8(50 \%)$ \\
\hline Average (b/n 10 \& 30) & $25(25 \%)$ & $10(40 \%)$ & 0 & $15(60 \%)$ \\
\hline Many (More than 30) & $45(45 \%)$ & $14(31 \%)$ & 0 & $31(69 \%)$ \\
\hline Total & $86(100 \%)$ & $32(31 \%)$ & 0 & $54(63 \%)$ \\
\hline
\end{tabular}

As table 10 reveals, on the issue of customer concentration (number of regular customers) as a measure of existence of networking and trade credit use, out of the 100 firms, 85 responded, $45 \%$ out of which said that they have more than 30 customers, $25 \%$ have between 11 and 30 and $16 \%$ have less than 10 regular customers. Comparing customer concentration and trade credit indicates that out of the 16 firms with less than 10 customers, $50 \%$ sell both on credit and cash while the other $50 \%$ sell on cash only. Out of the 25 firms which 
have between 10 and 30 customers, $60 \%$ sell both on credit and cash while $40 \%$ sell on cash only. From the 45 firms which have more than 30 customers $69 \%$ sell both on credit and cash and $31 \%$ sell on cash only.

Table 11: Transaction cost

\begin{tabular}{|c|c|c|c|c|}
\hline \multirow[b]{2}{*}{ Transaction cost is expensive } & \multirow[t]{2}{*}{ Number of firms } & \multicolumn{3}{|c|}{ Trading on cash/credit } \\
\hline & & Cash only & Credit only & Both Credit and Cash \\
\hline Yes & $59(63 \%)$ & $37(5 \%)$ & & $56(61 \%)$ \\
\hline No & $34(37 \%)$ & $22(8 \%)$ & 0 & $37(63 \%)$ \\
\hline Total & $93(100 \%)$ & $15(41 \%)$ & 0 & $19(59 \%)$ \\
\hline
\end{tabular}

On the issue of transaction cost as a measure of trade credit use (see table 11), out of the 100 firms, 93 responded, 65\% said that "yes" they believe the cost of changing loyal customer (due to problem of getting another customer soon or cost of losing the existing and finding a new) is expensive to them. However, 35\% said "no" they do not believe that the cost of changing loyal customer is expensive to them. Comparing Transaction cost and trade credit shows that out of the 59 firms which believe that the cost of changing loyal customer is expensive, $61 \%$ sell both on credit and cash while $39 \%$ sell only on cash. On the other hand out of the 34 firms which said that transaction cost is not relevantly expensive, $63 \%$ sell both on credit and cash while $37 \%$ sell on cash only, none of them sell only on credit.

\section{Discussion}

The main objective of the current study is to assess the effects of cooperation between suppliers and their customers on the sellers' trade approaches as well as to examine what types of trade approaches firms use (cash, credit, and/or both), how they apply their approaches and why they choose those approaches. To that objective, 11 items were analyzed (Tables 1-11).

On communication, findings indicate that, the firms use more personal visits to communicate among themselves. This can be inefficient and expensive means of communication and time consuming, though may be more effective at the end. We have also observed that only $3 \%$ of the firms have business association. This shows the overwhelming majority does not belong to business associations and the benefit that goes with having business association is being missed (McMillan, Woodruf, 1999, NG et al, 1999).

On networking, measured by the existence of communication with other firms, the finding reveals that the firms which have network or association sell more on both credit and cash compared to those that do not have. So, our findings on networking agree with our conceptual expectations. We expected that the firms having network or association face lesser risk, have more trust and can use more credit compared to those which do not have (Petersen, Rajan 1994). We found out that those sellers with established relationship and trust are willing to sell more on credit than those with less inter business experience and trust of others. In other words, the firms with network or association sell more on both credit compared to those which do not have.

On customer concentration, the firms with more customers sell more on both credit and cash, compared to those with less number of customers and this finding does not support our expectations. Consistent with other studies (Mian and Smith, 1992, Petersen, Rajan 1994), we expected that the firms with fewer customers sell more on both credit and cash compared to those with less customer concentration.

The findings on the experience of inter business relationship; show that, the firms having more experience sell less on credit and cash compared to those having more experience. So, as far as inter business experience is concerned our findings do not support our expectations. We expected that sellers with longer interfirm cooperation, established relationship and trust have higher possibility to sell on credit than those with less inter business experience and therefore trust of others.

The firms, who believe that the transaction cost is expensive, relatively sell less on both credit and cash compared to those which said "not". So, on Transaction cost our findings support our conceptual expectations. We expected that the firms who respond "yes" that the transaction cost is expensive to sell less on credit and more on cash as the practical observation reveals.

\section{Conclusions, limitations, and future research}

There are scarcities of studies on trade approaches firms use in developing countries and little is empirically known about the trade approaches firms use (cash, credit, and/or both), what influences their approaches and why they opt for those approaches in developing countries. Thus, this study empirically examined the trade approaches firms use and the factors that influence the decision to use those approaches in one developing country, Eritrea.

The research shows that experience of business relationship and membership in network is weak and therefore information is symmetric with the business firms in Eritrea. To reduce information asymmetry, firms may have to organize themselves in business associations. In their relationship with customers, sellers may have to offer two part trade credit terms with effective annual rate of interest well above their buyers marginal cost of 
capital and wait and see the reaction, signalling the payment risk. The government through the Ministry of Trade and Industry can make a good contribution by helping the business organizations to form inter firm and intra industry associations and prepare the ground for better business cooperation, competition and efficiency. The government can help the business firms to get oriented and updated on the modern approaches of business management in general and trade practice in particular. It can do this by organizing workshops through these business associations (such as Chamber of Commerce, the National Employers' Associations) so that the firms become better competitors locally, regionally and globally.

This study was conducted in only one developing country (Eritrea) and that restricts the generalization of the findings to other developing countries. Thus, in order to generalize and validate the findings of this study, we suggest that a similar study be conducted in other developing countries and additional research is needed to examine the robustness of the findings and generalizations. We believe that our research is a beginning and further in-depth research needs to be done on whether inter business cooperation influences trade credit to substantiate our research and make the finding solid evidence of the factors that influence trade credit transaction in small firms such as those in Eritrea. Particularly, more research is required to substantiate our conceptual expectations not supported by the empirical findings such as if trade credit is influenced by longer inter business experience and customer concentration.

In spite of the above limitations, however, this study addresses several gaps [literature] in trade approaches firms use in developing countries, like Eritrea. First, this study is the first in its kind. Second, this study has examined the extent to which different issues affect the decision to use trade approaches firms use in Eritrea, which to our knowledge has not been studied. And thus, it can be seen as an important addition to the literature on the trade approaches firms use in developing countries.

\section{References}

[1]. Boissay, F. \& Gropp R. (2013). Payment Defaults and Inter- firm Liquidity Provision. Review of Finance, $17(6): 1853-1894$.

[2]. Bouma, G.D. \& Atkinson G.B.L. (1995). A Handbook of Social Science Research: Comprehensive and Practical Guide for Students. Oxford University Press: Oxford.

[3]. Cole, R. A. (1998). Importance of Relationships to the availability of Credits. Journal of Banking and Finance, 22: 959-977.

[4]. Coleman, S. (2003). Free and Costly Trade Credit: A Comparison of Small Firms. Paper presented at the Annual Conference of the Academy of Entrepreneurial Finance, Chicago, Illinois, May 2, 2003.

[5]. Danielson, M.G. (2004). Bank Loan Availability and Trade Credit Demand. The Financial Review, 39: 579-600.

[6]. Deloof, M. \& Jegers, M. (1996). Trade Credit, Product Quality, and Intragroup Sales: Some European Evidence. Financial Management, 25(3): 33-43

[7]. Emery, G.W. (1984). A Pure Financial Explanation for Trade Credit. The Journal of Financial and Quantitative Analysis, 19(3): 271-285.

[8]. Ferris, J.S. (1981). A Transactions Theory of Trade Credit Use. The Quarterly Journal of Economics, 96(2): 243-270.

[9]. Gregory E. \& John, D. W. (1993). The demand for trade credit: an investigation of motives for trade credit use by small busin esses: A report to the Federal Reserve Board. Accessed on June 10, 2014 from http://www.federalreserve.gov/pubs/staffstudies/199099/ss165.pdf

[10]. Marotta, G. (2005). When do Trade Credit Discounts Matter? Evidence from Italian Firm Level Data. Applied Economics, 37: 403416.

[11]. McMillan, J. \& Woodruff, C. (1999). Inter-firm Relationships and Informal Credit in Vietnam. The Quarterly Journal in Economics, 114(4): 1285-1320.

[12]. Mian, S.L. \& Smith, C. W. (1992). Accounts Receivable Management Policy: Theory and Evidence. The Journal of Finance, 47(1): $169-200$.

[13]. Ministry of Industry and Trade (MoTI) (2010). Annual Report of the Ministry of Industry and Trade, Asmara, Eritrea.

[14]. NG, C.K., Smith, J.K., and Smith, R.L. (1999). Evidence on the Determinants of Trade Credit Terms Used in Inter-firm Trade. The Journal of Finance, 54(3): 1109-1129.

[15]. Peel, J.P., Wilson N. \& Howorth, C. (1999). Late Payment and Credit Management in the Small Firm Sector: Some Empirical $\begin{array}{lllll}\text { Evidence. } \quad \text { Accessed } & \text { on } & \text { April } & 2014\end{array}$ http://docis.info/docis/lib/ligo/rclis/dbl/cacmca/(2000)43\%253A11\%253C113\%253AMITS\%253E/www.cmrc.co.uk\%252Flatepay ment1999.pdf

[16]. Petersen, M.A. \& Rajan, R.G. (1994). The Effects of Credit Market Competition on Lending Relationships. The Quarterly Journal of Economics, 110(2): 407-443.

[17]. Petersen, M.A. \& Rajan, R.G. (1997). Trade Credit: Theories and Evidence. The Review of Financial Studies, 10(3): 661-691.

[18]. Pike, R., Cheng, N.S., Cravens K., \& Laminmaki, D. (2005). Trade Credit Terms: Asymmetric Information and Price Discrimination Evidence from Three Continents. Journal of Small Business and Accounting, 32: 1197-1236.

[19]. Porter, M.E. (1985), Competitive Advantages: Techniques for Analysis Industries and Competitors. The Free Press: New York.

[20]. Rappaport, A. (1986). Creating Shareholder Value: The New Standard for Business Performance. The Free Press: New York.

[21]. Scherr, F.C. (1989). Modern Working Capital Management, Text and Cases. Prentice-hall. Englewood Cliffs: New Jersey.

[22]. Scherr, F.C. (1996). Optimal Credit Limits. Financial Management, 25: 71-85.

[23]. Shank, J.K. \& Govidaradjan, V. (1993). Strategic Cost Management: The New Tool for Competitive. Free Press: New York.

[24]. Smith, J.K. (1987). Trade Credit and Informational Asymmetry. The Journal of Finance, Vol.42 No.4, $863-872$.

[25]. Tewolde, S., \& Eije, J.H. von (2007). Selfishness or co-operation: trade credit in manufacturing firms in Eritrea, Research in Accounting in Emerging Economies, volume 7, 369-387.

[26]. Tewolde, S. (2002). Working Capital Management, the case of Government owned, Transitional and Privatized Manufacturing Firms in Eritrea, unpublished $\mathrm{PhD}$ Thesis.

[27]. Van Horn, J.C. (1998). Financial Management and Policy. Upper Saddle River, NJ. 